\title{
SCREENING FOR HIGH-RISK HUMAN PAPILLOMAVIRUS BY REAL-TIME PCR AND ITS ASSOCIATION WITH CYTOLOGICAL ABNORMALITIES OF PAP SMEARS IN BAGHDAD
}

\author{
SALEH D.S. ${ }^{1}$, FADHIL H.Y.1* AND AL-HAMDANI F.G. ${ }^{2}$ \\ 1Department of Biology, College of Science, University of Baghdad, Baghdad-Al-Jadiria, Iraq. \\ ${ }^{2}$ Virology Department, The National Central Public Health Laboratory, Ministry of Health, Baghdad-Al-Andlus Street, Iraq. \\ *Corresponding Author: Email- hulayounis@scbaghdad.edu.iq
}

Received: December 09, 2012; Accepted: December 18, 2012

\begin{abstract}
Human Papillomaviruses (HPVs) are known to be etiological agents of cervical cancer and have been found in $99.7 \%$ of women with high-grade (HG) cervical intraepithelial neoplasia (CIN) pre-cancer. Testing of high-risk HPV (HR-HPV) has been proposed as a way of improving cervical screening, especially for women with low-grade (LG) Papanicolaou (Pap) smears. Therefore, the present study aimed to investigate the diagnostic correlation of real-time PCR technique with Pap smear results for 13 genotypes of HR-HPV in 415 of suspected women. Pap smear results showed the suspected women with abnormal and normal cytological changes were $79.3 \%$ (329/415) and $20.7 \%$ (86/415), respectively. In contrast, real-time PCR results showed that women with or without abnormal changes had HR-HPV DNA positive were $50.5 \%(166 / 329)$ and $10.5 \%$ (9/86), respectively. Thus, Pap smear results had no sensitive to predicate risky for LG-CIN women were observed. According to the real-time PCR results, the incident of HG or cancer was more associated with HR-HPV. Our findings indicated the real-time PCR test with the cytological test as a routine practice for women with LG-CIN reduces the incidence of HG or cancer. After that, the prospective studies should be appropriated to determine HR-HPV genotypes and viral load (copies/cell) with realtime PCR test as predicate risk-factor.
\end{abstract}

Keywords- Human Papillomavirus (HPV), Real-Time PCR, Papanicolaou (Pap) smear, Cervical abnormalities

Citation: Saleh D.S., Fadhil H.Y. and Al-Hamdani F.G. (2012) Screening for High-Risk Human Papillomavirus by Real-Time PCR and Its Association with Cytological Abnormalities of Pap Smears in Baghdad. International Journal of Microbiology Research, ISSN: 0975-5276 \& EISSN: 0975-9174, Volume 4, Issue 9, pp.-332-335.

Copyright: Copyright@2012 Saleh D.S., et al. This is an open-access article distributed under the terms of the Creative Commons Attribution License, which permits unrestricted use, distribution and reproduction in any medium, provided the original author and source are credited.

\section{Introduction}

Human Papillomaviruses (HPVs) are known to be etiological agents of cervical cancer and have been found in $99.7 \%$ of women with high-grade $(\mathrm{HG})$ cervical intraepithelial neoplasia $(\mathrm{CIN})$ precancer (such as CIN II/III and cancer) [1]. Testing of high-risk HPV (HR-HPV) has been proposed as a way of improving cervical screening, especially for women with low-grade (LG) (such as CIN I) Papanicolaou (Pap) smears [2]. The Pap smear test, as the most widely used cancer screening test in the world, is cost effective and organized screening provided a decline in cervical cancer mortality [3]. Testing of HPV DNA was recently introduced into clinical practice with the aim of identifying women at risk of cervical cancer, and encouraging results when are used in conjunction with the traditional cytology screening method. Many molecular methods for HPV DNA testing are currently available. Polymerase chain reaction (PCR) based methods amplifying nucleic acids of HPV are commonly used because of the limited sensitivity of Pap smear test leading to sample preparation and interpretation problems, insufficient serological tests and impossibility of in vitro cultures. Detection of HPV DNA, especially in latent infections, can be helpful in detecting cancer and precursor lesions [4]. Real-time PCR techniques have been developed to quantify HPV DNA in clinical samples. Also, real-time PCR is extremely reproducible, rapid and pertinent in a clinical setting [5]. Our observation suggests the HPV infections more frequency among Iraqi women. Therefore, the present study aimed to investigate the diagnostic correlation of realtime PCR technique with Pap smear results for 13 genotypes of HR -HPV in HG or LG pre-cancer. This could be considered very important in the early diagnosis and or prevention of cervical cancer.

\section{Materials and Methods}

\section{Studying Groups}

In current study, 415 of suspected women with different ages from $15-580$ old years were selected. Nearly all women had not been taken at least one Pap smear previously, who suffering from chronic inflammation and abnormal appearance of their cervix by gynecologist examination. Meanwhile, 25 health women as a control group were mainly depending on the absence of clinical symptoms and cervical cytological changes. All cervical samples were attending Women Health Center- Al-Alwia hospital and Al-kadhmia teach- 
ing hospital in Baghdad during the 2011.

\section{Pap Smear}

It is a simple and quick test. A special stick or brush was used to take a few cells from inside and around the cervix of women suspected. The sample, which contains cells and mucus, is then smeared onto a glass slide and send to a lab for a pathologist examination after Pap stain procedure [6].

\section{Cervical Scrape Samples}

Cervical scrape samples were collected in liquid transport medium such as PBS solution; cells were eluted from the spatula in $3 \mathrm{ml}$ of PBS [7]. The specimens could be transported at $4-30^{\circ} \mathrm{C}$ and stored at $-20^{\circ} \mathrm{C}$ for HPV DNA isolation.

\section{Real-time PCR HPV Test}

Real-time fluorescent $5^{\prime}$ exonuclease (Taq Man probe) assay was employed for HPV detection from the range of HR-HPV DNA (13 genotypes) most frequently found in different grades of cervical intraepithelial neoplasia, cervical tumors and health controls. HybriBio real-time PCR HPV detection kit (HybriBio co., LTD, Hong kong) was used for in vitro detection of HR-HPV DNA $(16,18,31,33$, $35,39,45,51,52,56,58,59$ and 68$)$ from scraped cervical cells according to supplied company instructions (www.hybribio.com) for DNA extraction and PCR amplification.

\section{DNA Extraction}

The DNA was extracted from $1 \mathrm{ml}$ of the cervical sample by centrifuging at $13000 \mathrm{rpm}$ for $1 \mathrm{~min}$. The pellet was washed in $500 \mu \mathrm{l}$ PBS solution, centrifuging at $13000 \mathrm{rpm}$ for $1 \mathrm{~min}$, and then discarded the supernatant clearly. The pellet was resuspended in 50 $\mu$ l lysis solution (Hybribio kit), mixes thoroughly, and then boiled for 10 min in water bath. Finally, the mixture was centrifuged at 13000 rpm at $10 \mathrm{~min}$, pipettes the supernatant to a new tube and stored at $-20^{\circ} \mathrm{C}$ for amplification.

\section{PCR Amplification}

The PCR amplification was performed in $20 \mu$ l total volume containing $17.5 \mu \mathrm{l} \mathrm{PCR} \mathrm{mix,} 0.5 \mu \mathrm{l}(5 \mathrm{U} / \mu \mathrm{l})$ Taq polymerase and $2 \mu \mathrm{l}$ DNA template. Taq Man probes are labeled hydrolysis probes. They consisted of an 18-22 bp oligonucleatides, which are labeled with a reporter dyes as 6-carboxyfluorescein (FAM) at the $5^{\prime}$ end. Amplification and detection were performed with an $A B I$ prism 7500 Sequence Detection System (Applied Biosystem). The amplification ramp included initial hold step of $10 \mathrm{~min}$ at $95^{\circ} \mathrm{C}$ to release the activity of the DNA polymerase. The hold step was followed by a two-step cycle consisting of $10 \mathrm{~s}$ at $95^{\circ} \mathrm{C}$ and $50 \mathrm{~s}$ at $58^{\circ} \mathrm{C}$ for a total of 45 cycles. Tubes that contained all PCR components but without template DNA (denoted no-template control [NTC] reactions) were used to ensure that the reagents were free of contamination [8].

\section{Statistical Analysis}

All values were calculated according to the positive results as percentages (\%). Differences between multiple groups and control group were analyzed by chi-square $\left(X^{2}\right)$ test. $A$ value of $P<0.5$ was considered statistically significant.

\section{Results \\ Pap Smear}

Results showed the suspected women with abnormal and normal cytological changes were $79.3 \%$ (329/415) and 20.7\% (86/415), respectively. Women with abnormal changes were comprised of $84.5 \%(278 / 329)$ as LG-CIN and $15.5 \%(51 / 329)$ of them in HG lesions [Table-1]. Thus, Screen test is important to reduce LG-CIN or it progression.

From the cytological test, $11.8 \%(6 / 51)$ of women with HG-CIN were constituted as squamous cell carcinoma that produced by HR -HPV, and $22.3 \%$ (39/175) of women with LG and HG-CIN was associated with koilocytosis criteria as the most important pathognomonic sign of HPV presence $[9,10]$.

\section{Real-time PCR}

High-risk HPV DNA prevalence in all suspected women was $42.17 \%(175 / 415)$ which appeared in pre-cancer and cancer lesions as $94.85 \%(166 / 175)$ and $3.43 \%(6 / 175)$, respectively. Our finding showed $50.5 \%(166 / 175)$ of women with abnormal changes and $10.5 \%(9 / 86)$ of women with normal cytological in Pap smear were positive for HR-HPV DNA [Fig-1], [Table-1]. The chi-square test used to check for correlations between HR-HPV DNA present and cytological changes was considered significant $(P<0.05)$.



Fig. 1- Distribution of HR-HPV DNA positive among infected women according to cytological changes appearance with Pap smear test.

Table 1- Distribution of Studying groups according to Pap smear results and Real-Time PCR HR-HPV DNA occurrence

\begin{tabular}{|lclc|}
$\begin{array}{l}\text { Changes } \\
\text { type }\end{array}$ & $\begin{array}{c}\text { No. of } \\
\text { Cases }\end{array}$ & $\begin{array}{c}\text { Positive no. (\%) } \\
\text { in Real-time PCR } \\
\text { HR-HPV DNA test }\end{array}$ \\
CIN I & 36 & $\begin{array}{l}\text { Binucleation, koliocytosis and hyperkerato- } \\
\text { sis associated with mild dysplasia }\end{array}$ & $18(4.3 \%)$ \\
(LG-CIN) & 108 & Cervicitis and mild dysplasia & Cervicitis and hyperplasia \\
& 61 & Monilliasis and mild dysplasia & $73(17.6 \%)$ \\
CIN II & 48 & Trichomonas and mild dysplasia & $21(5.1 \%)$ \\
CIN III & 96 & Cervicitis and moderate dysplasia & $7(1.7 \%)$ \\
SCC & 6 & Cervicitis, Sever dysplasia and & $13(3.1 \%)$ \\
Normal & 86 & Cervicitis and no cellular changes & $23(5.5 \%)$ \\
Cytology & 25 & No Changes and asymptoms & $5(1.2 \%)$ \\
Control & 25 & $6(1.4 \%)$ \\
Total & 440 & & $9(2.2 \%)$ \\
\hline
\end{tabular}


According to real-time PCR results, the incident of HG-CIN or cancer were more associated with HR-HPV which constituted 100\% $(6 / 6)$ of women with squamous cell carcinoma and $62.22 \%(28 / 45)$ of women were suffered from moderate to sever dysplasia had HRHPV DNA positive. Highest frequency of HR-HPV DNA positive was $47.5 \%(132 / 278)$ of women with LG [Fig-2]. On the other hand, the HR-HPV DNA observation of the total risky group in women with LG, HG-CIN and healthy women in cytology were $75.43 \%$ (132/175), 19.43\% (34/175) and 5.14\% (9/175), respectively.

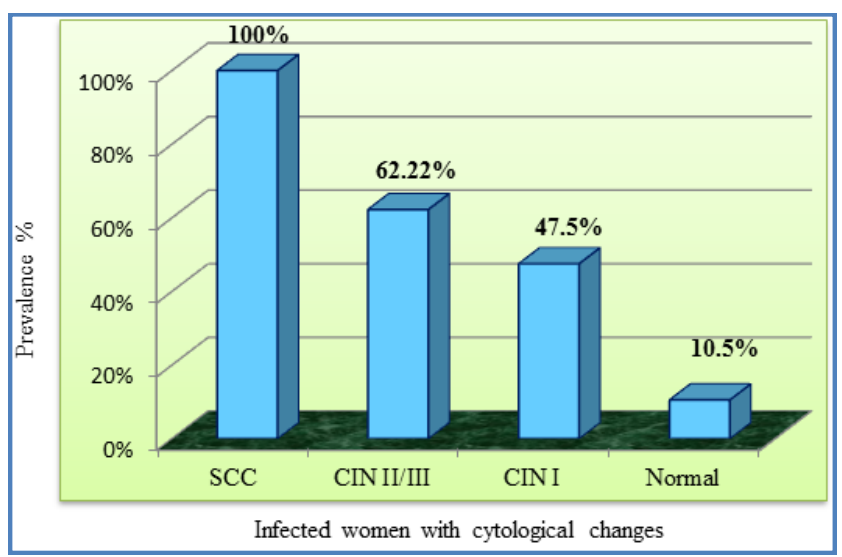

Fig. 2- Percentage of HR-HPV DNA positive among infected women according to risk groups of each cytological level.

From the results above, the sensitivity and specificity of cytopathology method for HR-HPV diagnosis were $50.5 \%$ and $89.5 \%$, respectively. Moreover, real-time PCR results showed more compatibility with Pap smear results for HG-CIN than LG-CIN diagnosis. Detecting of HR-HPV DNA in conjunction with Pap smear may improve the sensitivity of identifying LG pre-cancer that are associated with high-risk of progression.

\section{Discussion}

Real-time PCR the most advanced and sensitive of the molecular methods was used in the present study. Our finding showed HRHPV DNA presence in women with or without abnormal changes was more efficiency than cytological testing alone for clinical evidence. In this study, we gave a hint that consecutive detection of HPV DNA is due to either ongoing viral replication, reactivation of latent infections or new infections. The present study observed that HPV DNA percentages in studied Iraqi women were similar to those reported previously in many studies like $28.8 \%-61.3 \%$ of cases have been reported in women with abnormal cytology [1114]. On the other hand, the HPV prevalence in women with normal cytology was estimated in $5.2 \%-20 \%$ of cases [14-17]. These variations among studies are most likely reflecting the differences in the population studied with respect to risk factors for exposure to HPV and methods of evaluations. Although, women were had abnormal cytological changes, real-time PCR was showed those $77.9 \%$ (74/95) of LG and $20 \%$ (3/15) of HG-CIN as negative result for HRHPV DNA. This observation suggested the presence of either other microorganism like herpes virus, parasites and fungi which induce these cellular changes or women negative to real-time PCR probes for HR-HPV, may have missed which are positive to other HPV types not included in the probes or samples with very low number of virus DNA copies. Discordance between cytology and molecular detection found in women could be explained as a false-positive diagnosis of LSIL [18]. Meanwhile, real-time PCR results showed HR-HPV DNA was positive in women with normal cytology that similar to Arora et al. [12], suggested that the cases who are HPV positive for any of the high risk types but have concurrently negative Pap smear or no visible lesions should be followed up more frequently than the HPV negative cases as they have a substantially greater risk of developing an abnormal smear. Since morphological changes on cytology such as koilocytosis are not specific for oncogenic HPV [19], our finding showed that eight women had all criteria for HPV infection (such as koilocytosis) was HR-HPV DNA negative. Prevalence of HR-HPV DNA was more frequency in $H G$, thus a distinction between the pathological diagnoses of HG-CIN (CIN II/III) may be important in future clinical studies of real-time PCR HR-HPV screening and the prevention of cervical cancer.

\section{Conclusion}

Our findings indicated the real-time PCR test with the cytological test as a routine practice for women with LG-CIN reduces the incidence of $\mathrm{HG}$ or cancer. After that, the prospective studies should be appropriated to determine HR-HPV genotypes and viral load (copies/cell) with real-time PCR test as predicate risk-factor.

\section{Acknowledgment}

I deeply thanks to all staff member of cytology unit/Women Health Center/Al-Alwia hospital for samples collection. Also special thanks to director Iman M. Aufi/MSc. Virology and all staff member of National Influenza Laboratory/National Central Public Health Laboratory for using real-time PCR system.

\section{References}

[1] Howley P.M., Lowy D.R. (2007) 5th Field Virology, Published by Lippincott Williams and Wilkins, USA, 2299-2354.

[2] García D.A., Cid-Arregui A., Schmitt M., Castillo M., Briceño I. and Aristizábal F.A. (2011) The Open Virol. J., 5, 70-79.

[3] Shors T. (2009) Understanding Viruses, Published by Jones and Bartlett, Sudbury, Massachusetts Canada, 98-102.

[4] Dinc B., Rota S., Onan A., Bozdayi G., Taskiran C., Biri A. and Guner H. (2010) Braz. J. Infect. Dis., 14(1), 19-23.

[5] Zaravinos A., Mammas I.N., Sourvinos G. and Spandidos D.A. (2009) The Int. J. of Biol. Marker., 24, 215-222.

[6] Marcband L.M.D., Mundt M.S., Klein G.T. and Agarwal M.D. (2005) Wisconsin Med. J., 104(6), 51-55.

[7] Tabora N., Ferrera A., Bakkers M.J.E., Massuger F.A.G. and Melchers W.J.G. (2008) Am. J. Trop. Med. Hyg., 78(5), 843846.

[8] Moberg M., Gustavsson I. and Gyllensten U. (2003) J. Clinc. Microbiol., 41(7), 3221-3228.

[9] Krawczyk E., Suprynowicz F.A., Liu X., Dai Y., Hartmann D.P., Hanover J. and Schlegel R. (2008) Am. J. Pathol., 173, 682688.

[10]Aggarwal S., Arora V.K., Gupta S., Singh N. and Bhatia A. (2009) Diagn. Cytopathol., 37, 174-177.

[11]Sherman M.E., Wang S.S., Wheeler C.M., Rich L., Gravitt P.E., Tarone R. and Schiffman M. (2003) Cancer Epidemiol. Bi- 
Screening for High-Risk Human Papillomavirus by Real-Time PCR and Its Association with Cytological Abnormalities of Pap Smears in Baghdad

omarkers Prev., 12, 1038-1044.

[12]Arora R., Kumar A., Prusty B.K., Kailash U., Batra S. and Das B.C. (2005) Eur. J. Obstet. Gynecol. Reprod. Biol., 121(1), 1049.

[13]Zavarei M.J., Hamkar R., Dana V.G., Delforoosh M., Shojamoradi M.H. and Gilani M.M. (2008) Iranian J. Publ. Health., 37, 101-106.

[14]Dursun P., Senger S.S., Arslan H., Kuscu E. and Ayhan A. (2009) BMC Infect. Dis., 9, 191-200.

[15]Clifford G.M., Gallus S., Herrero R., Muñoz N., Snijders P.J., Vaccarella S., Anh P.T., Ferreccio C., Hieu N.T., Matos E., Molano M., Rajkumar R., Ronco G., de Sanjosé S., Shin H.R., Sukvirach S., Thomas J.O., Tunsakul S., Meijer C.J. and Franceschi S. (2005) Lancet., 366(9490), 991-8.

[16]de Sanjose S., Diaz M., Castellsague X., Clifford G., Bruni L. and Munoz N. (2007) Lancet Infect. Dis., 7(7), 453-9.

[17]Bao Y.P., Li N., Smith J.S. and Qiao Y.L. (2008) Int. J. Gynecol. Cancer., 18(1), 71-9.

[18]Gonzalez-Losa M.R., Rosado-Lopez I., Valadez-Gonzalez N., Camara-Mejia J. and Puerto-solis M. (2006) Revista Colombianade Obstet. Gynecol., 1, 31-35.

[19]Miyahara G.I., Simonato L.E., Mattar N.J., Camilo jr D.J. and Biasoli E.R. (2011) Mem. Inst. Oswaldo Cruz., 106(2), 166-169. 